University of Nebraska - Lincoln

DigitalCommons@University of Nebraska - Lincoln

Faculty Publications: Department of

Entomology

Entomology, Department of

2021

\title{
Honey bee foraged pollen reveals temporal changes in pollen protein content and changes in forager choice for abundant versus high protein flowers
}

\author{
Gabriela Quinlan \\ Michigan State University, quinlang@msu.edu \\ Meghan Milbrath \\ Michigan State University, milbrat2@msu.edu \\ Clint Otto \\ US Geological Survey, Northern Prairie Wildlife Research Center, cotto@usgs.gov \\ Autumn Smart \\ University of Nebraska-Lincoln, asmart8@unl.edu \\ Deborah D. Iwanowicz \\ U.S. Geological Survey, Kearneysville, diwanowicz@usgs.gov
}

See next page for additional authors

Follow this and additional works at: https://digitalcommons.unl.edu/entomologyfacpub

Part of the Entomology Commons

Quinlan, Gabriela; Milbrath, Meghan; Otto, Clint; Smart, Autumn; Iwanowicz, Deborah D.; Cornman, Robert; and Isaacs, Rufus, "Honey bee foraged pollen reveals temporal changes in pollen protein content and changes in forager choice for abundant versus high protein flowers" (2021). Faculty Publications:

Department of Entomology. 948.

https://digitalcommons.unl.edu/entomologyfacpub/948

This Article is brought to you for free and open access by the Entomology, Department of at DigitalCommons@University of Nebraska - Lincoln. It has been accepted for inclusion in Faculty Publications: Department of Entomology by an authorized administrator of DigitalCommons@University of Nebraska - Lincoln. 


\section{Authors}

Gabriela Quinlan, Meghan Milbrath, Clint Otto, Autumn Smart, Deborah D. Iwanowicz, Robert Cornman, and Rufus Isaacs 


\title{
Honey bee foraged pollen reveals temporal changes in pollen protein content and changes in forager choice for abundant versus high protein flowers
}

\author{
Robert Scott Cornman ${ }^{\mathrm{e}}$, Rufus Isaacs ${ }^{\mathrm{a}}$ \\ ${ }^{a}$ Department of Entomology, Michigan State University, 578 Wilson Rd., East Lansing, MI 48824, United States \\ ${ }^{\mathrm{b}}$ US Geological Survey, Northern Prairie Wildlife Research Center, 8711 37th St. SE, Jamestown, ND 58401, United States \\ ${ }^{\mathrm{c}}$ Department of Entomology, University of Nebraska-Lincoln, 103 Entomology Hall, Lincoln, NE 68583, United States \\ ${ }^{\mathrm{d}}$ US Geological Survey, Eastern Ecological Science Center, 11649 Leetown Rd., Kearneysville, WV 25430, United States \\ ${ }^{\mathrm{e}}$ US Geological Survey, Fort Collins Science Center, 2150 Centre Ave, Building C., Fort Collins, CO 80526, United States
}

Gabriela Quinlan $^{\mathrm{a}, *}$, Meghan Milbrath ${ }^{\mathrm{a}}$, Clint Otto ${ }^{\mathrm{b}}$, Autumn Smart ${ }^{\mathrm{c}}$, Deborah Iwanowicz ${ }^{\mathrm{d}}$,

\section{A R T I C L E I N F O}

\section{Keywords:}

Apis mellifera

Honey bee

Metabarcoding

Nutrition

Landscape

Floral resources

\begin{abstract}
A B S T R A C T
Protein derived from pollen is an essential component of healthy bee diets. Protein content in honey bee foragedpollen varies temporally and spatially, but the drivers underlying this variation remain poorly characterized. We assessed the temporal and spatial variation in honey bee collected pollen in 12 Michigan apiaries over 3 summers (2015-2017). We simultaneously monitored forage in flowering habitats (uncultivated floristically-rich areas and conservation program land) near these apiaries throughout the growing season. We used these data, along with data from the literature on plant pollen protein content, to determine if honey bees collected a greater proportion of pollen from plant species growing in higher abundance or from plant species that have higher protein content. Protein content in honey bee collected pollen decreased from July to September every year, and there were among-year differences in pollen protein, highlighting the temporal variation in protein collected by these insects. Pollen protein was spatially consistent and broad-scale land use categories were not correlated with pollen protein content. Rather, our findings suggest flowering habitats found across land use categories can support honey bee foraging, which may confound broader land use effects. In early July and in early September, colonies collected a greater proportion of pollen from plants that grew in greater abundance in flowering habitats, but from late July through August, a greater proportion of pollen was collected from high-protein taxa, regardless of abundance. This suggests different factors may influence pollen forager decision-making throughout the season as colony needs and/or available forage communities change. Insights into the role of plant abundance and protein content on foraging could deepen our understanding of honey bee foraging behavior and help to inform habitat restoration programs for improved honey bee nutrition outcomes.
\end{abstract}

\section{Introduction}

Pollinator health is an issue of national and international concern (Pollinator Health Task Force, 2014; Williams, 2003). Poor nutrition is one of the major stressors on the health of both honey bees and wild bees, principally due to a deficient availability of floral resources (Goulson et al., 2015; vanEngelsdorp and Meixner, 2010). Pollen from flowers is the only natural source of protein for bees, and pollens can range widely in protein content from $2.5 \%$ to $61 \%$ (Buchmann, 1986; Roulston et al., 2000). A sufficient quantity of high quality protein (between 20\% and 25\%) is essential to honey bee adult survival and brood rearing (Schmidt et al., 1987) and thus overall colony fitness (Haydak, 1935; Khoury et al., 2013; Ribeiro, 2011; Roulston and Cane, 2002), though bee nutrition is complex and multifaceted (see reviews, Brodschneider and Crailsheim, 2010; Vaudo et al., 2015). The depletion of pollen resources in the fall triggers honey bee colonies to slow brood rearing and transition into an overwintering modality (Mattila and Otis, 2007). Pollen protein also plays a key role in honey bee health and immunocompetence (Alaux et al., 2010; DeGrandi-Hoffman et al., 2010; Di Pasquale et al., 2013; Tritschler et al., 2017). In a study of various

\footnotetext{
* Corresponding author.

E-mail address: quinlang@msu.edu (G. Quinlan).
} 

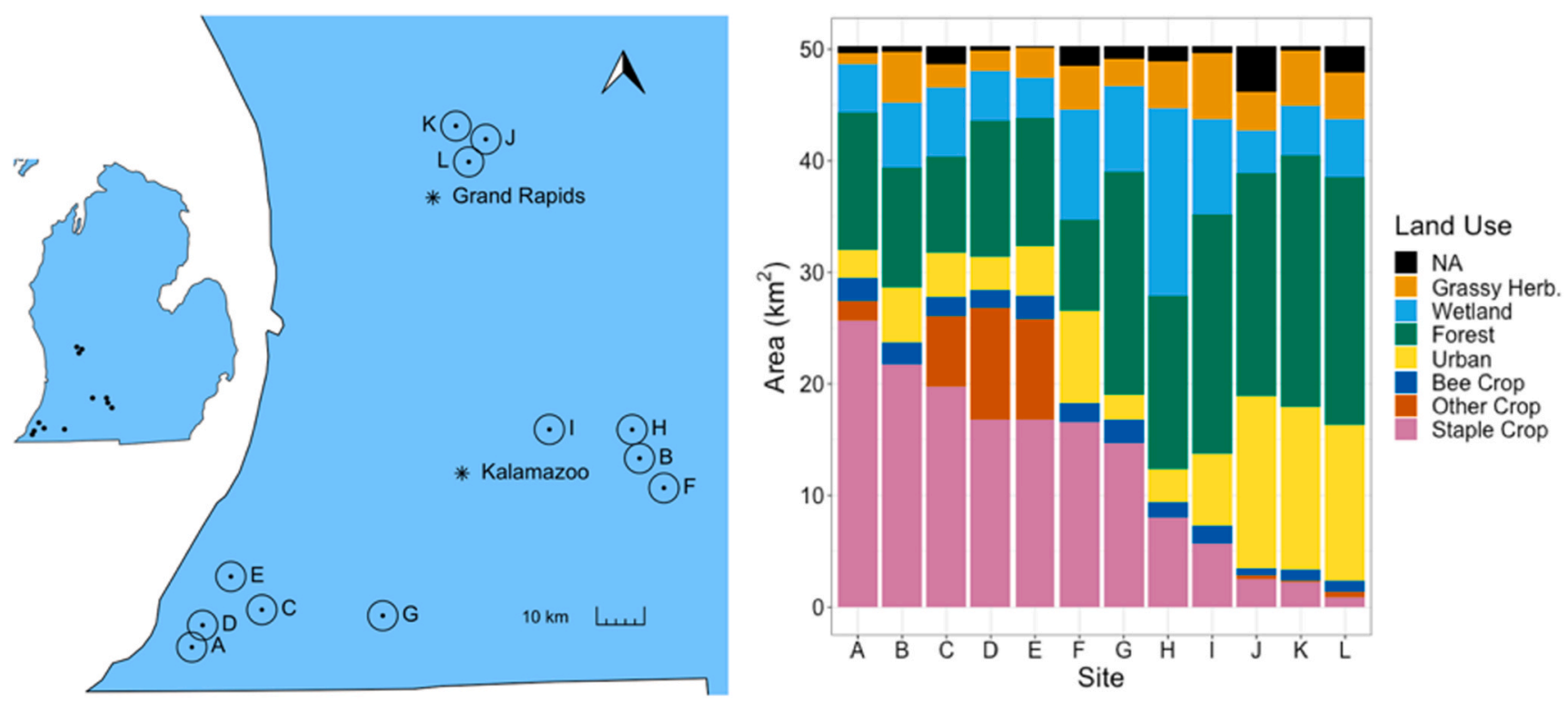

Fig. 1. Map of 12 apiary locations in southwest Michigan, US, represented by points surrounded by a $4 \mathrm{~km}$ foraging range. Pollen was collected from apiaries B, C, E, and F in 2015, apiaries B-F and H-L in 2016, and A-L in 2017. Stars show the location of major cities for orientation purposes. Land use area (km²) within 4 km of each site is shown in the stacked bar plot. Land use data is from the 2017 Cropland Data Layer (US Department of Agriculture National Agricultural Statistics Service, 2018), binned into eight categories: NA (undefined, barren, water), grassy-herbaceous fields (hay, wildflower, switchgrass, fallow, and pasture), wetlands, forests, urban, bee-supportive crops (alfalfa, canola, and sunflower), staple crops (soybean, corn, and small grains), and other crops (all other crops).

pollen diets, pollen protein content was positively correlated with hypopharyngeal gland and ovary development, indicating protein content is a good proxy for honey bee diet quality (Pernal and Currie, 2000).

Multiple studies have shown temporal and/or spatial variation in the protein content of pollen that honey bees collect (Donkersley et al., 2014; Liolios et al., 2015; Simanonok et al., 2020). Within a single apiary in Greece, researchers observed within-year changes in honey bee foraged pollen protein, with spring forage being higher in pollen protein than summer forage (Liolios et al., 2015). Researchers in the United Kingdom (UK) described a similar decrease in beebread (stored pollen) protein from July through September (Donkersley et al., 2014). Pollen protein likewise peaked in July and decreased through September in the northern Great Plains of the United States (US) (Simanonok et al., 2020). Both these UK and US studies also describe an effect of landscape on pollen protein. In the northern Great Plains of the US, the effect of land cover composition surrounding the apiaries on pollen protein changed throughout the summer (Simanonok et al., 2020). In the UK, pollen protein was negatively correlated with the area of surrounding cultivated land (Donkersley et al., 2014). High intensity agriculture has also been linked to low pollen protein in a two-apiary study in North Dakota (Smart et al., 2018a). Due to the importance of pollen protein for colony health, understanding spatiotemporal variation in protein content could provide insight into the quality of forage landscapes throughout the season, thereby supporting beekeeper decision-making.

Bloom phenology and floral abundance constrain the taxonomic composition of foraged pollen (Pernal and Currie, 2001). But, as social foragers, honey bees are capable of recruiting to high-quality floral patches within the surrounding landscape (Seeley, 1986; Steffan-Dewenter and Kuhn, 2003). In particular, mass-blooming flowers have been shown to be highly attractive to honey bee foragers (Beekman and Ratnieks, 2000; Danner et al., 2016). To what extent forage nutrition influences foraging behavior, however, is still an area of debate. While some field studies (Beekman et al., 2016) and laboratory studies (Pernal and Currie, 2002) suggest that foragers are incapable of differentiating pollen protein content, Levin and Bohart (1955) found that forager visitation matched protein levels in five out of six choice diets, and Fewell and Winston (1992) showed that foragers choose higher-nitrogen (protein-rich) pollens but only when a colony has access to abundant stored pollen. Colonies can sense when stored pollen is depleted or low in protein (Pernal and Currie, 2001), but are thought to compensate by increasing overall pollen foraging effort rather than foraging for higher-protein pollens (Fewell and Winston, 1992; Pernal and Currie, 2001). Foragers also seem to balance the ratio of proteins to lipids (between 1:1 and 2:1) in the pollen that is collected (Vaudo et al., 2020). This all suggests that at some level, honey bees are capable of detecting and regulating pollen protein intake to colonies through foraging behavior.

In this study we sought to understand how foraged pollen protein changes over time and space in a diverse Michigan agroecosystem and the role of honey bee foraging behavior in regulating foraged pollen composition. Specifically, we aim to determine how pollen protein content changes temporally (annually and summer-long) and spatially (among colonies, apiaries, and with land use categories) and to determine how floral abundance and floral protein quantity influence the composition of foraged pollen.

\section{Methods}

\subsection{Site selection}

Our study took place in southwestern Michigan, a landscape containing small farms with diverse crops, interspersed in a matrix of forests, urban, wetlands, and grassy-herbaceous land (US Department of Agriculture National Agricultural Statistics Service, 2018). During the summers (July-September) of 2015-2017, pollen was collected from two honey bee colonies each at multiple commercial apiaries in southwestern Michigan (Fig. 1). In 2015, pollen was collected at four apiaries ( $\mathrm{N}=8$ colonies, apiaries $\mathrm{B}, \mathrm{C}, \mathrm{E}, \mathrm{F}$ ). In 2016 six apiaries were added for a total of ten apiaries ( $\mathrm{N}=20$ colonies, apiaries B-F and H-L), and in 2017 two additional apiaries were added for a total of 12 apiaries $(\mathrm{N}=24$ colonies, apiaries A-L). Temperature was similar among years but July-September precipitation was slightly higher in 2017 (Michigan State University, 2020).

Land use within a $4 \mathrm{~km}$ radius of each apiary was determined using the Cropland Data Layer (CDL) for each year (US Department of Agriculture National Agricultural Statistics Service, 2018). We delineated a 
$4 \mathrm{~km}$ radius due to its prior use in honey bee land use studies in the Midwest, US (e.g. Smart et al., 2018b, 2019). Furthermore, an assessment of waggle dances in Europe indicates that in summer there is a high probability of bees foraging within $2-3 \mathrm{~km}$ of the hive, but the possibility of foragers traveling $5 \mathrm{~km}$ or further exists (Couvillon et al., 2014). Using the raster, rgdal, and sf packages in R (Bivand et al., 2019; Hijmans et al., 2020; Pebesma, 2018), CDL land covers were binned into seven land use categories, modified after (Smart et al., 2016): wetlands, grassy-herbaceous fields (hay, wildflower, switchgrass, fallow, and pasture), staple crops (soybean, corn, and small grains), bee-supportive crops (alfalfa, canola, and sunflower), other crops (all other crops, e.g. vegetables, tree fruits, and vineyards), urban, and forests. While many crops may support bees, the category of bee-supportive crops includes crops specifically known to provide abundant nectar and which are considered high-value forage (Smart et al., 2016). Land use around the apiaries was representative of regional land use; the area of each land use category around the apiaries was not different from 500 randomly generated $4 \mathrm{~km}$ buffer locations within the extent of the apiary locations. However, our 12 sites represented less variance in grassy-herbaceous fields, bee-supportive crops, and urban land than the region (Table A.1).

\subsection{Pollen collection}

Every two weeks from early July to early September in 2015, 2016, and 2017, pollen traps (Superior Pollen Traps, Mann Lake, Hackensack, $\mathrm{MN}$ ) were activated on two colonies per apiary for $72 \mathrm{~h}$ (Brodschneider et al., 2019; Cornman et al., 2015; Smart et al., 2017; Smart et al., 2018a). The start date of each biweekly collection period was within 3 days of the other years. In 2015, pollen was collected five times, in 2016 pollen was collected four times (no early July collection), and in 2017 pollen was collected four times (no late August collection). We collected 181 samples total, as 35 samples were not obtained due to insufficient quantity of collected pollen. Insufficient pollen quantities may result from foragers bypassing the trap or a colony dying. Pollen was transported in coolers from the field and stored at $-20^{\circ} \mathrm{C}$ until processing. Pollen samples were weighed, and a $15 \mathrm{~g}$ subsample of homogenized pollen was dried at $60{ }^{\circ} \mathrm{C}$ for $60 \mathrm{~h}$. After drying, the pollen was ground with a mortar and pestle and a $1 \mathrm{~g}$ subsample of the prepared pollen was sent to the USGS National Fish Health Research Laboratory at the USGS Eastern Ecological Science Center in Kearneysville, WV for DNA sequencing. The remaining prepared pollen was sent to Midwest Labs in Omaha, NE for percent crude protein content analysis (AOAC 990.03). Quantification of crude protein analysis used a Dumas combustion assay (Chang and Zhang, 2017), with a correction factor of 6.25, which is commonly used for pollen (Roulston et al., 2000). While other approaches (e.g., Bradford assay) are more sensitive and quantify total soluble proteins, measures of crude protein content are common in the literature (Roulston et al., 2000), and therefore better suited to our purposes. In 2015, twenty-six pollen samples were assessed for protein and twenty-eight for sequencing; in 2016, sixty-two samples were assessed for protein and sixty-six for sequencing; and in 2017, eighty-six samples were assessed for protein and thirty-two for sequencing.

\subsection{Pollen DNA extraction and library prep}

Pollen composition was estimated by paired-end sequencing of an approximately $900 \mathrm{bp}$ fragment of the internal transcribed spacer (ITS) region of the nuclear ribosomal locus, using methods modified from Cornman et al. (2015). Briefly, $300 \mathrm{bp}$ paired-end sequencing performed on the Illumina MiSeq recovered non-overlapping fragments of the ITS1 and ITS2 spacer regions. Amplicons were produced in two steps, the first using standard primers to generate a high concentration of input template. These were created using primers ITS5a (Stanford et al., 2000) and ITS4 (White et al., 1990). The thermocycler program for these primers consisted of an initial denaturation step of $95^{\circ} \mathrm{C}$ for $5 \mathrm{~min}$, followed by
40 cycles of 30 , s at $95^{\circ} \mathrm{C}, 35 \mathrm{~s}$ at $47^{\circ} \mathrm{C}$ and $1.5 \mathrm{~min}$ at $72{ }^{\circ} \mathrm{C}$, with a final extension of $72{ }^{\circ} \mathrm{C}$ for $10 \mathrm{~min}$ (Cornman et al., 2015). An appropriately sized amplification product was confirmed via electrophoresis of $5 \mu \mathrm{l}$ of the reaction product through a $1.2 \%$ I.D.N.A. agarose gel (Cambrex Corporation, East Rutherford, NJ) at $100 \mathrm{~V}$ for approximately $45 \mathrm{~min}$. Polymerase chain reaction products were cleaned with the Qiagen PCR Purification kit (Valencia, CA) and quantified on a Qubit, using DNA High Sensitivity Assay kit (Agilent, Santa Clara, CA). All samples were diluted in $10 \mathrm{mM}$ Tris buffer ( $\mathrm{pH}$ 8.5) to a final concentration of $5 \mathrm{ng} / \mu \mathrm{l}$ to prepare libraries for the Illumina MiSeq.

The second step used the same ITS primers modified with the sequencing adapters specified in Illumina's $16 \mathrm{~S}$ metagenomic sequencing library preparation protocol (CT \#: 150442223, Rev.B). All amplicon libraries were prepared following the manufacturer's protocols. DNA size spectra of the indexed libraries was confirmed on the Agilent 2100 Bioanalyzer using the Agilent DNA 1000 Kit (Santa Clara, CA). The libraries were then quantified with the Qubit ds DNA HS Assay Kit (ThermoFisher Scientific, Grand Island, NY) and normalized to $4 \mathrm{nM}$ using $10 \mathrm{mM}$ Tris $\mathrm{pH} 8.5 \mathrm{~A}$ final $12 \mathrm{pM}$ preparation of pooled libraries was created with a $10 \%$ PhiX control spike.

\subsection{Pollen DNA sequencing}

Reads were trimmed of adapters and low-quality bases with the bbduk package (Joint Genome Institute, 2019), specifying a kmer size of 15 to detect internal adapter matches (a minimum kmer size of 10 at read edges) and a requiring a minimum Phred-scaled quality score of 10 . Reads less than $150 \mathrm{nt}$ after trimming were discarded, and only intact read pairs were retained. Forward reads were clustered at $97 \%$ identity using vsearch (Rognes et al., 2016). Cluster representatives were then scaffolded with their reverse reads using an arbitrary gap size of $25 \mathrm{~N}$ 's. Scaffolds were then reclustered at $97 \%$ to account for variation contributed by the reverse read, producing an initial set of operational taxonomic units (OTUs).

Taxonomic assignment of OTUs used the lowest common ancestor (LCA) method (Huson et al., 2007), which is based on the distribution of global alignment scores for each representative sequence. OTU representative sequences were aligned to the NCBI nucleotide database (download date 3/19/2018) with the Basic Local Alignment Search Tool (BLAST + v. 2.3.0). OTUs were then assigned to the lowest taxonomic rank encompassing all species scoring within $3 \%$ of the highest bit score for that OTU summed across the reads of each pair. Species level assignments were demoted to genus if the average percent identity of matches was less than $95 \%$ and genus level assignments were demoted to family if matches were less than $90 \%$ on average.

Operational taxonomic unit abundance was not drawn from the vsearch cluster size but instead estimated by mapping reads to OTUs with bowtie2 (Langmead and Salzberg, 2012) as this approach allows greater control of alignment parameters. Reads were mapped using the "local" mapping mode, which is more permissive to mismatches at read edges while still imposing a minimum alignment score. The "score-min" parameter for local mapping was set to "G,80,8" (see Langmead and Salzberg, 2012 for details of the alignment scoring method) and valid alignments were required to have $97 \%$ identity in the aligned region, with no more than five skipped bases at read ends and fewer than five indel positions within the alignment (Table A.2).

Raw OTU counts were censored to a minimum of 10 counts globally. Then, taxa that made up less than $0.5 \%$ of the sample were dropped to account for low-rate sample crosstalk that arises from demultiplex error (e.g. Le et al., 2018). Taxa that are not documented to grow in Michigan based upon the USDA Plants database (State Search, 2020) were removed as potential taxonomic error or laboratory contamination (Ageratina adenophora, Anemone hupehensis, Clematis terniflora, and Heliotropium curassavicum). It is possible that $A$. hupehensis was grown as an ornamental, but it was only found in four samples and was removed out of caution. ITS2 metabarcoding alone may not be a reliable method 
for estimating absolute quantity of taxa (Richardson et al., 2015b). While using multiple loci can improve quantitative estimates (Richardson et al., 2015a), such an approach was beyond the scope of our study. Instead, we calculated a relative proportion of pollen taxa, normalized across samples, which can be used to compare pollen composition over all pollen samples (Simanonok et al., 2021). Counts were converted into within-sample proportions and log-ratio transformed with the geometric mean as the reference value (Aitchison, 1982). A single scalar was then added to all cells to yield positive values. The resulting composition of normalized, relative proportions are referred to as proportions.

\subsection{Pollen protein review}

Protein content values for identified taxa were obtained from the literature using the Roulston et al. (2000) review of pollen protein from 377 species, as well as a key word search. Additional sources were found using Google Scholar with the search terms "pollen" and "protein." These terms were then modified to also include "bee" and "crude protein". After exhausting the results of this search, protein data for individual taxa were found using the taxa's name along with the terms "pollen" and "protein" (Table A.3). For pollen identified to genus or family, we averaged all records from the literature at that taxonomic level or below. For example, all species and genera belonging to Asteraceae were averaged to estimate Asteraceae protein content. Likewise, when multiple protein records were found in the literature for a single taxon, protein values were averaged for analysis. While much of the literature uses the same method to quantify protein as we used, other methods (e.g., bicinchoninic acid (BCA), Bradford assay) may yield slightly different results (Chang and Zhang, 2017).

\subsection{Assessments of forage in flowering habitats}

In July of each year (2015-2017) we conducted floral transect surveys within the $4 \mathrm{~km}$ buffer surrounding the apiaries and revisited these locations two more times each year (August and September). Transects were conducted within floristically-rich areas, including roadsides and private properties where permission could be obtained. These areas will henceforth be referred to as "flowering habitats." Private properties included both unmanaged land and land managed under a conservation program (e.g., Conservation Reserve Program, Pheasants Forever). We were unable to randomly or systematically choose flowering habitats due to the unpredictable and undocumented nature of unmanaged flowering habitats and the lack of publicly available location records for land under various conservation programs. Therefore, flowering habitats were chosen during drive-by surveys within each $4 \mathrm{~km}$ buffer area in July. The start location of each transect was randomized using a random number generator to select the entering direction and number of paces into the field from which each transect was begun and proceeded northward. We counted and identified all actively flowering herbaceous stalks at a total of 734 transect locations from 2015 to 2017 (average of $27 \pm 1$ (mean \pm sd) transect locations/site/year), with different flowering habitats and transect locations chosen each year. In 2015 and half of 2016, transects were $25 \mathrm{~m}$ by $2 \mathrm{~m}$, while in half of 2016 and all of 2017 , transects were conducted over a $20 \mathrm{~m}$ by $2 \mathrm{~m}$ area, a $22 \%$ difference in total area. The two different 2016 lengths were equally interspersed temporally and among fields. Because we are not attempting to compare transects in different years, no correction was applied.

After flowering habitats and transect locations were selected, the land use (seven binned CDL categories) of the transect locations was determined using the raster package (Hijmans et al., 2020). Land use was only determined for flowering habitats not known to be under conservation management. The land use classification of the flowering habitats were unknown at the time of the floral transects, and land use was not evident based on ground truthing of these habitats. Flowering habitats identified within land use categories that are not known for supporting herbaceous flowering plants (e.g., forests, staple cropland) likely occurred below the resolution of the CDL and along the edges or in marginal areas.

\subsection{Statistical analysis}

All statistical analyses were completed in R-studio version 3.6.3 (RCore Team, 2020). The spatiotemporal levels of organization in this study were bi-weekly sample period (within year), year, apiary, and apiary by year (26 levels $=4$ (2015 apiaries) +10 (2016 apiaries $)+12$ (2017 apiaries)).

Within-year differences in pollen protein were determined using generalized linear mixed effects models (GLMM) with the lme 4 package (Bates et al., 2015). Bi-weekly sample period (factor) and year were treated as fixed effects. Year was treated as a fixed effect because it only contained three levels. Apiary by year and unique colony identity were treated as random intercepts. A compound symmetry error structure was used due to the low variance explained by unique colony identity in all of the models. Apiary was excluded as a random effect because it caused convergence issues and singular model fit when included in addition to the random intercept of apiary by year. Post-hoc pairwise Tukey comparisons were then conducted to determine how pollen protein varied between sampling periods (Hothorn et al., 2008). To determine temporal trends in the protein content of pollen collected by each colony over the season, sampling round was treated as numeric and the slope of a line of best fit was calculated for each colony with three or more pollen samples.

Yearly differences in pollen protein were calculated using GLMM by setting year as a fixed effect, while sample period ( 5 levels), apiary by year (26 levels), and unique colony identity (54 levels) were random intercepts.

Spatial differences among apiaries in pollen protein were calculated, with apiary and year as fixed effects and sample period, apiary by year, and unique colony identity as random effects. To determine the effect of each land use category and their interactions with biweekly sampling period on pollen protein, we used seven separate GLMMs with the interaction of land cover and biweekly sampling round as the fixed effects, and apiary by year and unique colony identity as random effects. The capacity of these broad-scale land use categories to support flowering habitats was compared by visualizing the mean and standard error of floral abundance (number of flowering stalks), floral richness (number of unique taxa), and abundance of common honey bee pollen plants (number of flowering stalks) in transects across these land use categories.

The correlation between a taxon's protein content and its proportional makeup in each pollen sample was determined for each sampling round using GLMMs. First, pollen sample proportion was logittransformed, then regressed with protein content and year as predictor variables and apiary as a random effect. Apiary was excluded as a random effect if it did not contribute to the model. Differences among sampling rounds in the protein content of taxa that appeared in the pollen samples during that round were calculated using analysis of variance. Similarly, the relationship between the abundance of a plant genus in the transect samples of flowering habitats surrounding an apiary and the proportion of that genus in the pollen (logit-transformed) was calculated within each round using GLMMs with log-plus-one transformed abundance and year as the predictor variables and apiary as a random effect, unless it explained $0 \%$ of the variance and caused singular fit. Transect records of floral stalk abundance were grouped within each pollen sampling round by treating transects which fell within the first 15 days of the month as "early" and those which fell after as "late." 


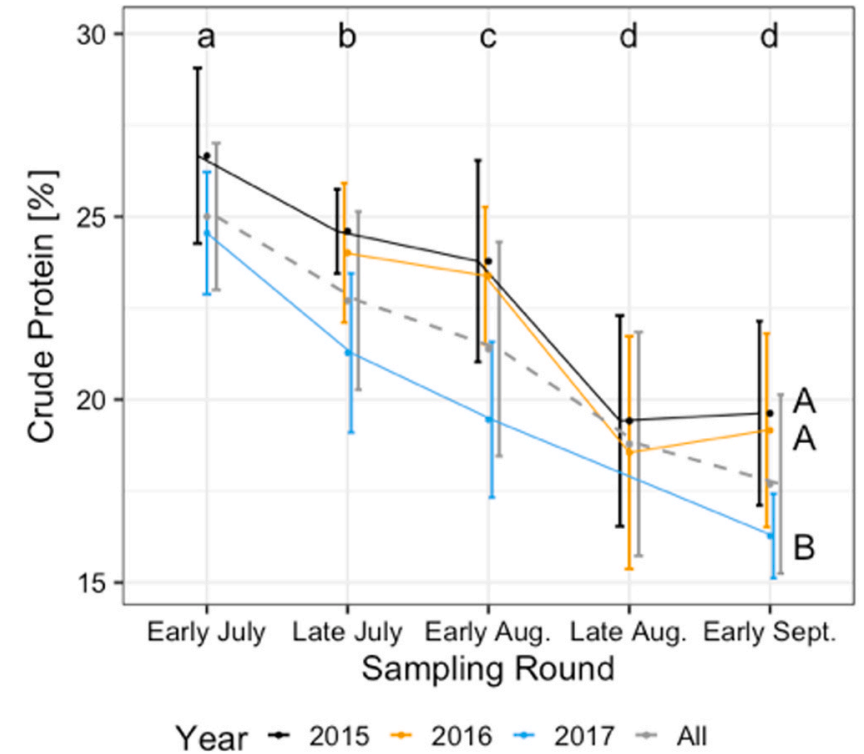

Fig. 2. Percent crude protein content (mean $\pm \mathrm{sd}$ ) in collected pollen over time by sampling round. Pairwise differences $(\alpha<0.05)$ among biweekly sampling rounds (pooled years) are indicated by different lowercase letters across the top of the graph, while pairwise differences $(\alpha<0.05)$ among years (pooled rounds) are indicated by different uppercase letters along the right side of the graph.

\section{Results}

\subsection{Pollen protein varies temporally (within and between years)}

Protein content of honey bee collected pollen from the summers of 2015-2017 in southwestern Michigan ranged from $11.7 \%$ to $31.3 \%$ among all sites and timepoints, averaging $21.1 \pm 3.6 \%$ (mean $\pm 1 \mathrm{sd}$ ) per pollen sample. Each year, pollen protein content was highest in July and decreased to early September (Fig. 2) (2015: $F_{4}, 10.78=6.70$, $\mathrm{p}<0.01,2016: \mathrm{F}_{3}, 51.06=22.87, \mathrm{p}<0.01,2017: \mathrm{F}_{3}, 62.38=97.99$, $\mathrm{p}<0.01$ ). On average, pollen protein content declined $2 \%$ each sampling period, for a total of an $8 \%$ change in protein from early July to early September. The colony with the greatest change in protein

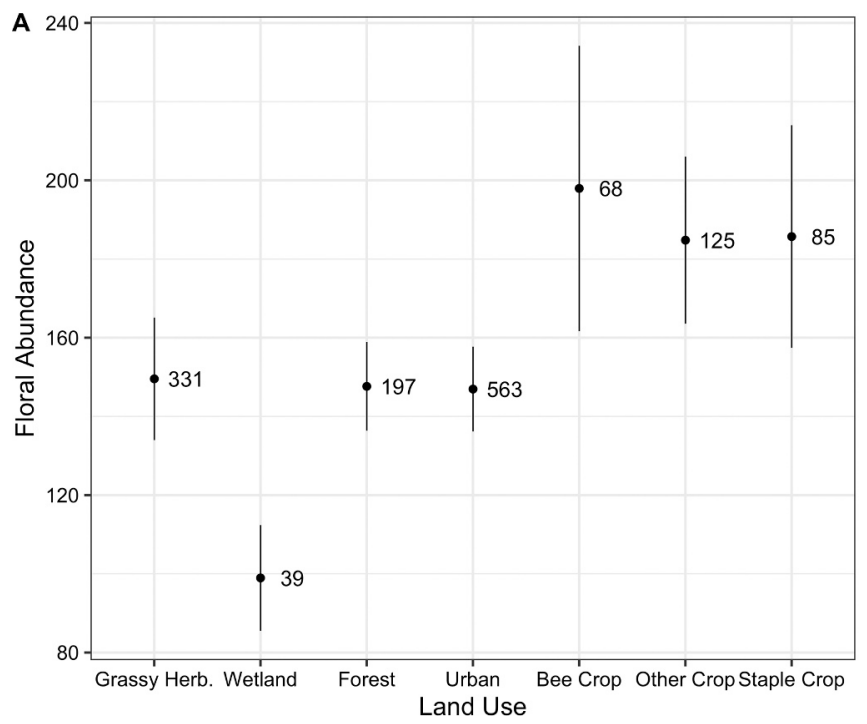

throughout the season had a decrease of $3.9 \%$ per sample period. Only one colony in one year had no decrease in pollen protein over the summer, instead showing no summer-long change. The summer-long decrease in protein content was observed across the landscape, occurring in almost every apiary when year was included in the model as a fixed effect. Only one apiary (I) (Fig. 1) had no significant change in pollen protein over sampling time $\left(\mathrm{F}_{5,9}=2.30, \mathrm{p}=0.14\right)$, but still showed a trend for decreasing protein content. Due to a small sample size (colony loss and pollen trap malfunction), we could not determine within-year trends for apiary (D) (Fig. 1).

Pollen protein varied from year to year $\left(\mathrm{F}_{2,20.39}=22.96, \mathrm{p}<0.01\right)$. When pooled across all sampling rounds, pollen in 2017 had a lower protein content compared to 2015 and 2016, which were not different from each other (Fig. 2). Pollen protein in 2017 was on average $3 \%$ lower than 2016 and 3.6\% lower than 2015.

\subsection{Pollen protein is spatially consistent and not correlated with $C D L$ land use categories}

Pollen protein content did not vary among apiaries across the growing season $\left(\mathrm{F}_{11}, 8.45=0.66, \mathrm{p}=0.75\right)$. By year, there was little difference in protein content among apiaries (2015: $\mathrm{F}_{2}, 3.20=2.06$, $\left.\mathrm{p}=0.27 ; 2017: \mathrm{F}_{11}, 11.97=1.46, \mathrm{p}=0.26\right)$. In $2016\left(\mathrm{~F}_{7}, 51.01=2.20\right.$, $\mathrm{p}=0.05$ ) the only significant difference was between apiary $\mathrm{E}$ and $\mathrm{L}$ $(\mathrm{z}=-4.11, \mathrm{p}=0.01)$,

None of the land use categories were strongly associated with pollen protein content, overall. The only land use category that showed any correlation with pollen protein was a negative correlation with the socalled bee-supportive crops category $\left(\mathrm{F}_{1}, 24.50=7.03, \mathrm{p}=0.01\right)$. However, bee-supportive crops made up at most $4.3 \%$ of the forage landscape and the partial- $\mathrm{R}^{2}$ of was less than 0.01 , which casts doubt on this as an ecologically meaningful relationship.

\subsection{Flowering habitats are found across land use classifications}

All seven simplified land cover categories supported flowering habitats. Of the 734 transect locations assessed, 117 were classified by the CDL as grassy-herbaceous fields, 66 as forests, 43 as non-staple cropland, 29 as staple cropland, 24 as bee-supportive cropland, 13 as wetland, and 190 as urban. Land cover classification information was not obtained for the 243 transects known to be under conservation management, and

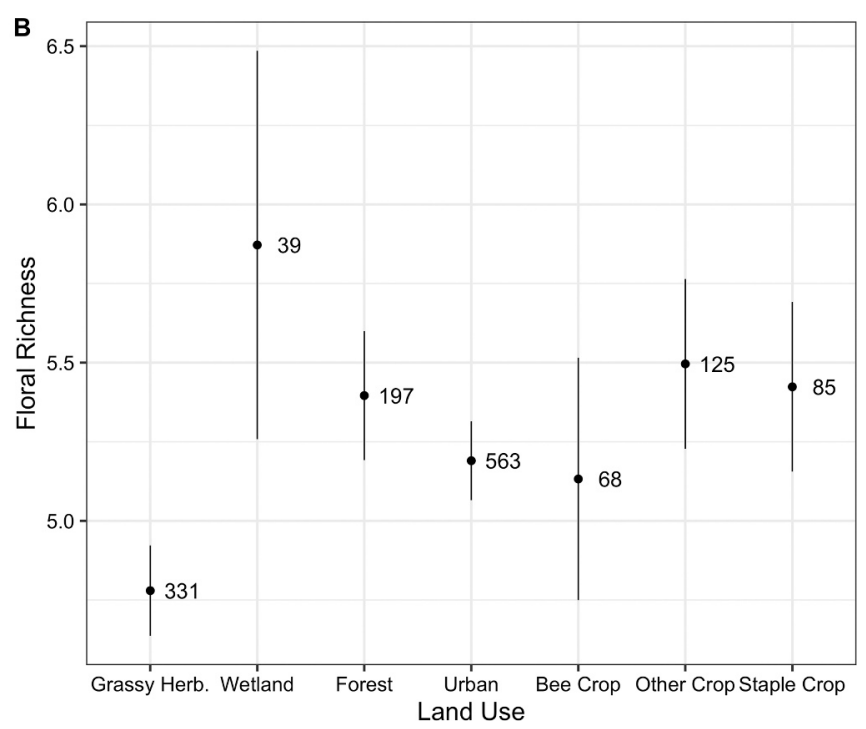

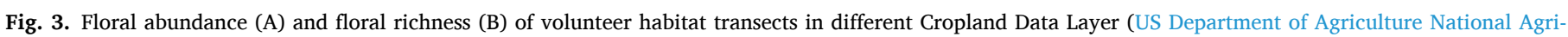

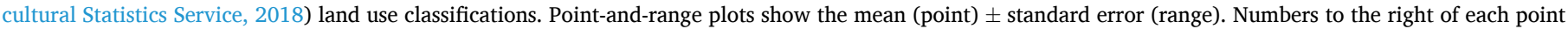
indicate the number of transect assessments (unique location and sampling round) from which the mean and standard error were calculated. 

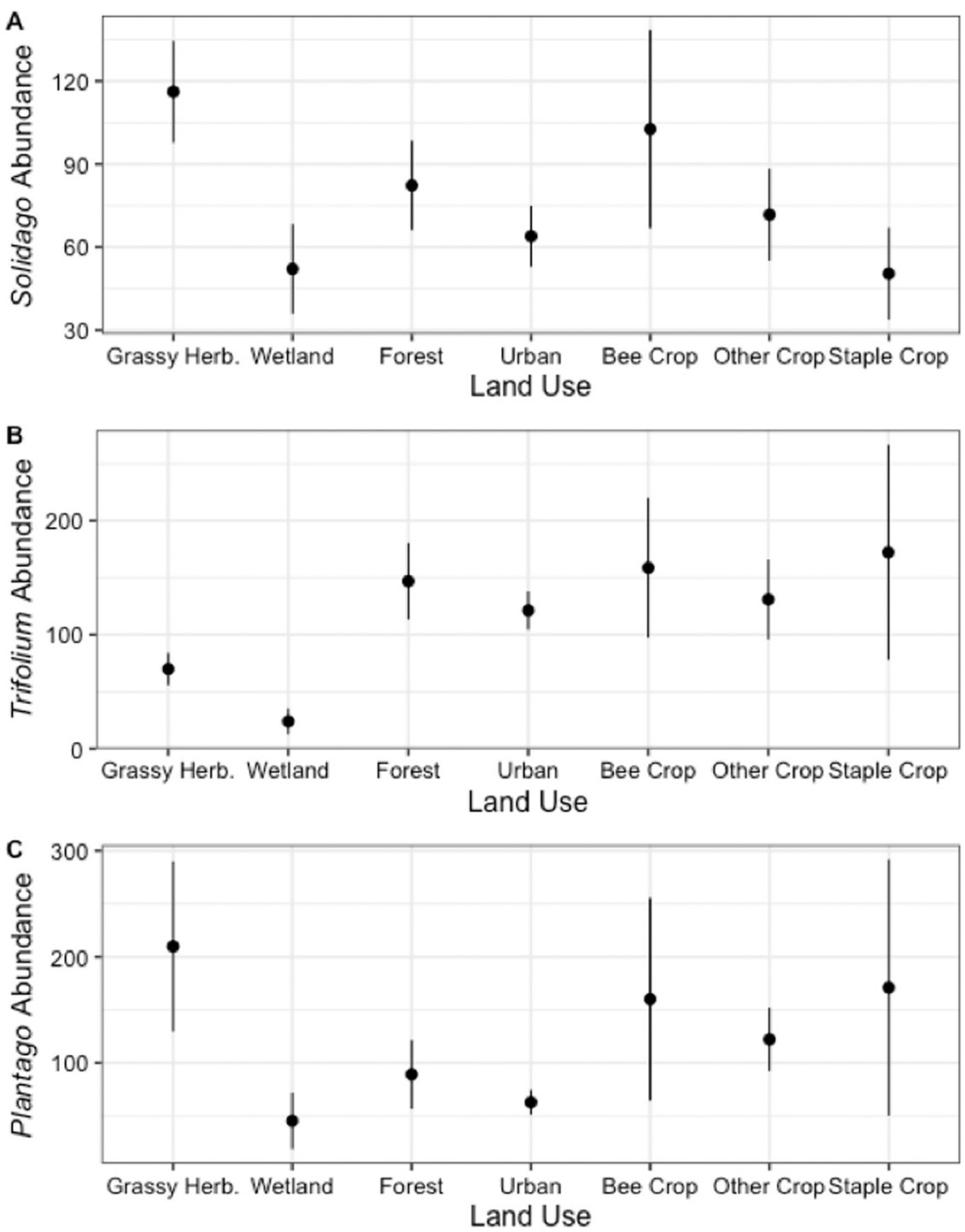

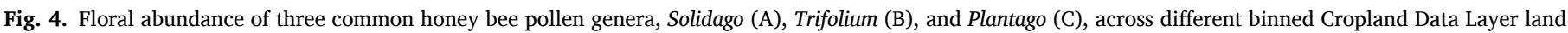

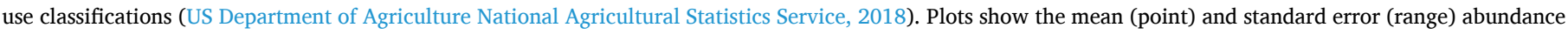
of each genera per transect in volunteer habitats within $4 \mathrm{~km}$ of 12 research apiaries in Michigan, US.

location data was incorrectly recorded for 9 transects. There was substantial variation in floral abundance (Fig. 3A), floral richness (Fig. 3B), and the abundance of common plants from which pollen was collected (Fig. 4) within and among CDL land covers, suggesting that flowering habitat quality cannot be predicted based upon broader land use classification. Furthermore, common plants that pollen was collected from appeared in flowering habitats across all land covers (Fig. 4), showing that these flowering habitats support key pollen species, regardless of broader land use classification.

\subsection{Wildflowers make up a large proportion of honey bee summer pollen}

We identified 60 unique plant taxa, spanning 47 genera, in foraged pollen over the three years of our study (Fig. 5). On average, $6.1 \pm 2.9$ taxa were identified per pollen sample, with samples ranging in richness from 1 to 15 taxa. We were able to find protein content information for 40 of the 60 identified taxa in the literature (Table A.3).

Among those which made up the greatest proportion of pollen in each year were common wildflower taxa including Trifolium (clover) in early July, followed by Plantago (plantain), Daucus (wild carrot), and Solidago (goldenrod) in early September (pollen proportion refers to the normalized, relative proportion). Invasive plant species' pollen was also present in high proportions and included Lythrum salicaria (purple loosestrife) and Centaurea stoebe (star thistle) (State of Michigan, 2021) (Fig. 5). Pollen species also included crops (e.g. Zea mays (corn) and Glycine max (soybean)) and ornamentals (e.g. Hydrangea).

\subsection{Honey bees collect a greater proportion of pollen from plants found in} high abundance in flowering habitats in early July and early September

The most common species observed in flowering habitats included Solidago altissima (tall goldenrod, $\mathrm{n}=42,120,13 \%$ total observations), Daucus carota (wild carrot, $\mathrm{n}=30,326,10 \%$ ), Plantago lanceolata (narrowleaf plantain, $\mathrm{n}=27,191,9 \%$ ), Trifolium pratense (red clover, $\mathrm{n}=25,121,8 \%$ ), and Centaurea stoebe (star thistle, $\mathrm{n}=24,259,8 \%$ ).

Honey bees collected a greater proportion of pollen from plants that were observed in greater abundance within flowering habitats (floristically-rich habitats where transects were conducted) in early July $\left(\mathrm{F}_{1,10}\right.$ $=22.14, \mathrm{p}<0.01)$ and early September $\left(\mathrm{F}_{1,59}=8.55, \mathrm{p}<0.01\right)$ (Fig. 6A). In early July, Trifolium was a highly abundant genus collected in high proportions. Likewise, the genus Solidago played a key role in the relationship between floral abundance and pollen proportion in early 
A

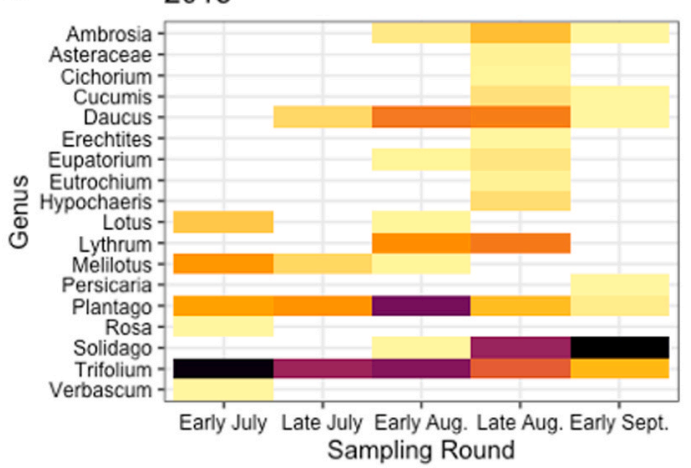

B

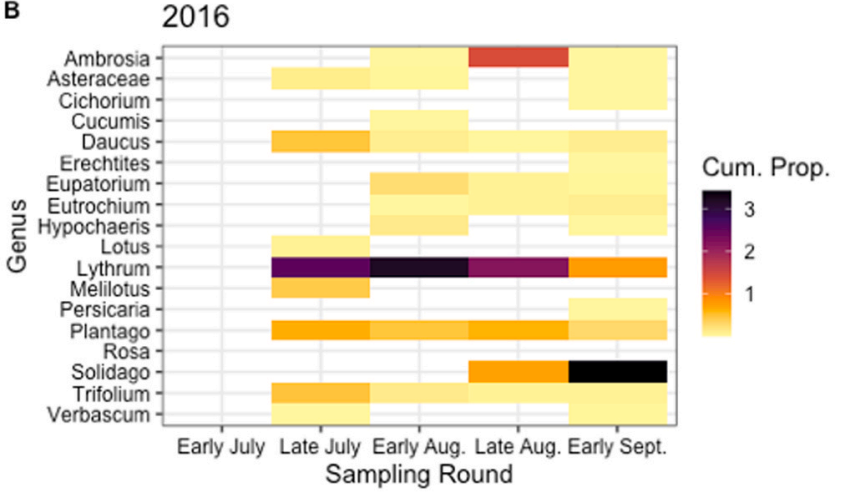

C

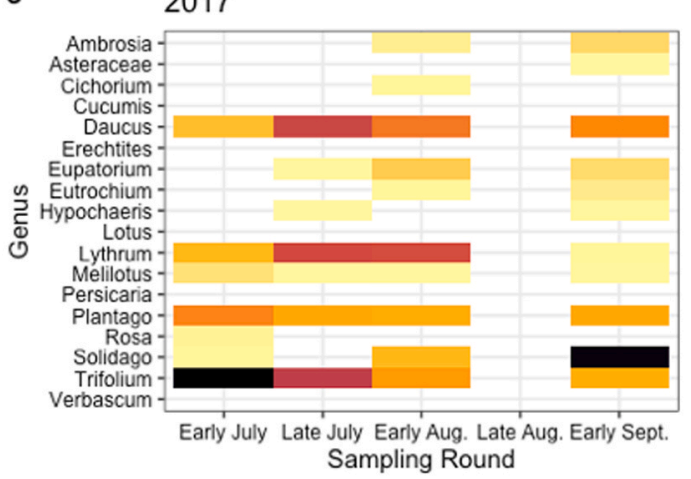

Fig. 5. Cumulative normalized proportion of pollen genera within each sampling year/ round, in 2015 (A), 2016 (B), and 2017 (C) by sampling round early July (not sampled in 2016), late July, early August, late August (not sampled in 2017), and early September based upon metabarcoding reads. Plotted genera include only those present in 2015 pollen samples.

September (Fig. 6A). There was no correlation between floral abundance and pollen proportion in late July $\left(\mathrm{F}_{1,48}=0.83, \mathrm{p}=0.37\right)$, early August $\left(\mathrm{F}_{1,32.62}=0.44, \mathrm{p}=0.51\right)$ or late August $\left(\mathrm{F}_{1,51}=0.55, \mathrm{p}=0.46\right)$.

\subsection{Honey bees collect a greater proportion of pollen from high-protein plants in late July-late August}

Higher-protein pollens were collected in greater proportions from late July throughout August (late July: $\mathrm{F}_{1}, 84.90=6.37, \mathrm{p}=0.01$; early August: $F_{1}, 83.90=5.08, p=0.03$; late August: $F_{1,139}=6.25, p=0.01$ ). The strength of this relationship (estimated coefficient) was greatest in late July and decreased each sampling round (Fig. 6B). There was not, however, a significant relationship between the proportion of a given taxa in honey-bee foraged pollen and that taxa's protein content in early July $\left(F_{1}, 52=2.13, p=0.15\right)$. In early September, colonies collected more pollen from lower-protein plants $\left(\mathrm{F}_{1}, 151=4.18, \mathrm{p}=0.04\right)$. This was not a result of change in available protein throughout the summer; there was no difference among sampling rounds in the average protein content of collected taxa $\left(\mathrm{F}_{4}, 90=0.87, \mathrm{p}=0.48\right)$.

\section{Discussion}

We show strong evidence that protein content in honey bee collected pollen decreases from early July to September in Michigan, US. We also observed annual variation in pollen protein, which shows the nutritional landscape for these bees is dynamic across years. Although not the focus of our study, this suggests regional weather patterns may play a role in influencing the nutritional landscape of bees across an entire region and growing season. Protein content was spatially consistent across apiary sites and was not strongly correlated with broad-scale land use categories, demonstrating the weakness of the CDL as a predictive tool for estimating bee forage. Wildflower taxa made up a large proportion of honey bee pollen diets, likely due to the abundance of these plants in flowering habitats, which were found across land use categories. Our results also suggest foragers collect a higher proportion of pollen from protein-rich taxa at certain times, which provides insight into the role of protein as a driver of foraging behavior.

Protein content in the pollen samples collected by honey bees was within the range considered sufficient for supporting honey bee adult survival and brood rearing from early July through early August (20-25\%) (Di Pasquale et al., 2013; Schmidt et al., 1987), but pollen protein dropped below this level in most apiaries from late August through early September. This was also the case in a recent study conducted in the northern Great Plains (Simanonok et al., 2020). This late season drop in protein may affect colony health, particularly because this is when winter honey bees are being raised (Döke et al., 2015), and overwintering success is higher in bees fed high-protein natural diets (DeGrandi-Hoffman et al., 2016). Previous studies have found that foragers collect more from low-protein pollens to maintain colony protein levels (Liolios et al., 2015) particularly during periods of pollen dearth (Fewell and Winston, 1992; Pernal and Currie, 2001). Alternatively, honey bee colonies may need less protein later in the season as brood production is greatly reduced in preparation for winter (Mattila and Otis, 2007). Recent work in Arizona suggests that collection of seasonal pollens align with the seasonal nutritional needs of honey bee colonies (DeGrandi-Hoffman et al., 2018). While DeGrandi-Hoffman et al. (2018) did not observe differences in overall protein content between spring and fall pollens, they did observe higher concentrations of amino acids in spring pollen and showed that bees fed out of season pollen had a reduced nutritional state (hypopharyngeal gland size).

Shifting colony-level needs for protein may also explain why colonies foraged for more abundant taxa some weeks and more protein-rich taxa other weeks. We observed a gradual reduction in correlation strength between the protein content of foraged pollen composition from late July through August. By early September, honey bees foraged on abundant, though protein-poor pollen, notably Solidago spp. A summerlong decrease in colonies' need for protein does not explain, however, why colonies did not collect from high-protein taxa in early July. In early July (and early September) the attractiveness of abundant forage likely influenced foraging decisions (Danner et al., 2016; Seeley, 1986). Future studies that experimentally assess the effects of multiple interacting drivers of nutrient foraging (protein content, abundance, etc.) could further our understanding of foraging behaviors. In particular, the influence of other nutrients (lipids, micronutrients, amino acids and fatty acids) (Brodschneider and Crailsheim, 2010) could also be influential.

It should be noted that there was large variability among reported protein records for some species, likely in part due to differences in protein quantification methods (Chang and Zhang, 2017) (e.g. Verbascum sp. as reported in Liolios et al., 2015: 29.82\% versus Vaudo et al., 2020: 6.4\%). Environmental conditions also influence pollen protein content (Ziska et al., 2016). Data also did not exist for a third of taxa in our study. Therefore, these correlative observations should be 

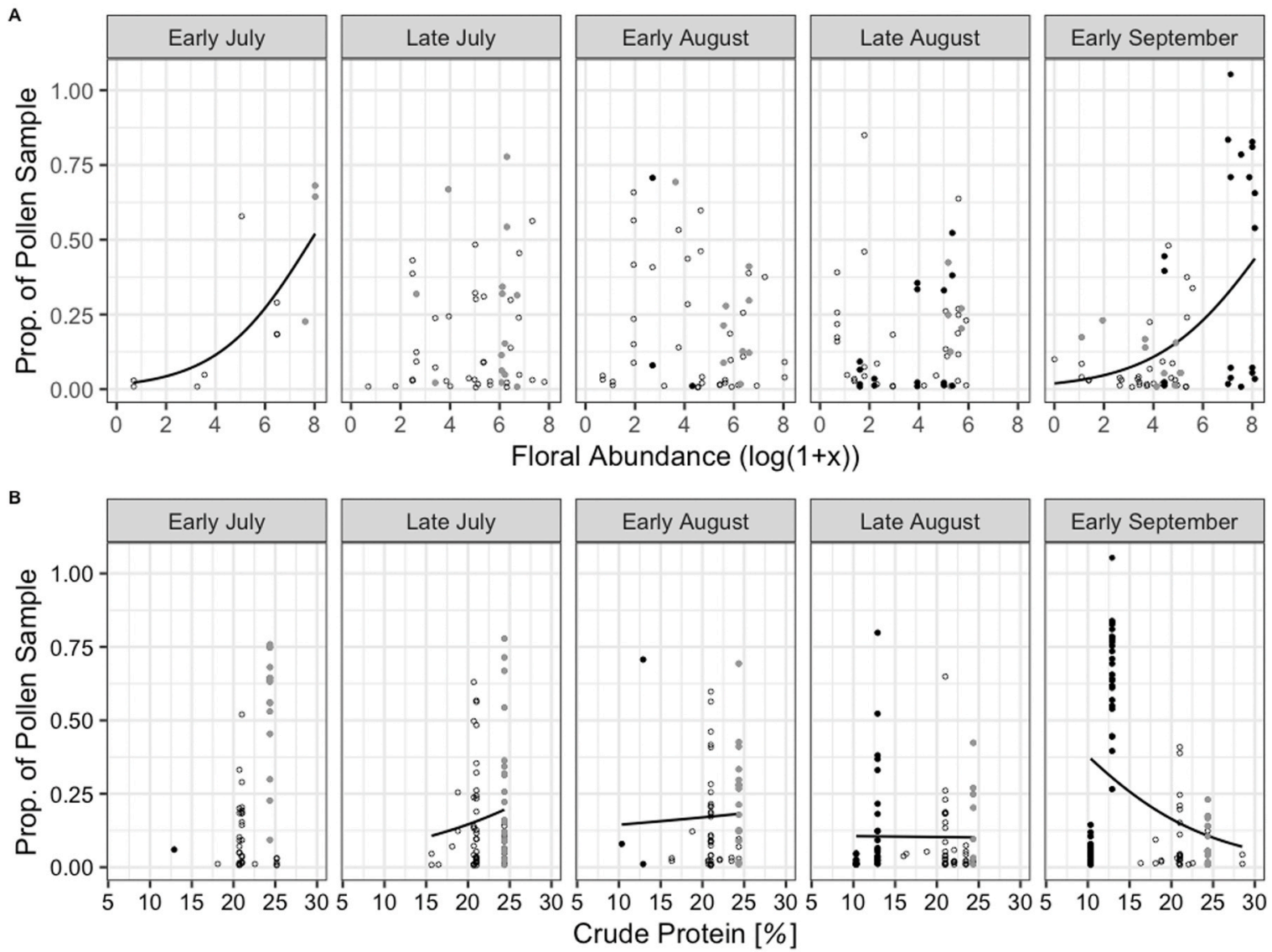

Crude Protein [\%]

\section{Genus • Solidago • Trifolium}

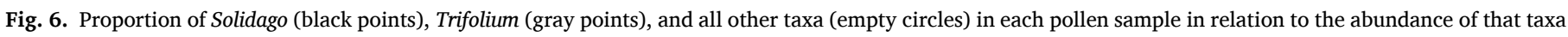

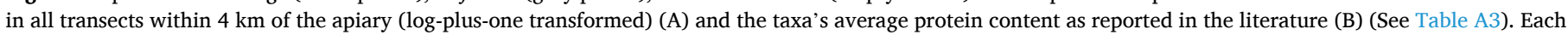

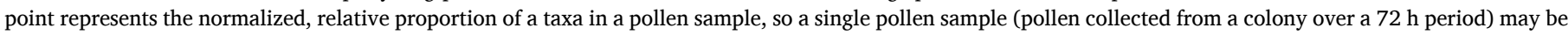

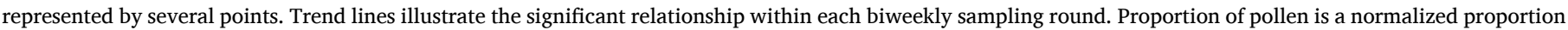
of metabarcoding read counts per sample. Proportions are presented as untransformed values but were logit-transformed for analysis.

interpreted with caution. Additional data on species-specific pollen protein would be a valuable asset to our understanding of bee foraging ecology.

In contrast to a previous study in the UK (Donkersley et al., 2014), surrounding land use was not identified as a primary driver of pollen protein content. Further investigation could be made into the role of bee-supportive crops, which was identified as the only significant land use driver, by selecting sites that capture a greater range of this land use than was represented in our study. However, our results suggest that honey bees are capable of finding forage of similar protein content across landscapes in diverse agroecosystems by capitalizing on the abundant forage found in flowering habitats. These flowering habitats were found across many land use classifications, and showed significant variation both across and within classifications. While previous studies have used remotely-sensed land use classifications as a metric for quantifying pollinator forage quality (e.g. Gallant et al., 2014; Koh et al., 2016; Otto et al., 2018; Thogmartin et al., 2017), our results highlight the importance of not treating all land of a given classification the same, particularly when it comes to large-scale habitat modeling of native bees that may have more specialized diets (Baldock et al., 2019). Improved remote sensing and classification of flowering habitat is needed to improve our ability to connect land use patterns to bee nutritional resources.

Many studies have recognized honey bees' close association with common, uncultivated wildflowers, or so-called weeds based upon foraged pollen identity (Bretagnolle and Gaba, 2015; Requier et al.,
2015) and foraging behavior (Quinlan et al., 2021). These wildflowers species were common in both the pollen and transects in our study. Previous studies in the Midwest describe a similar progression and composition of pollen communities for honey bees to what we observed (Lau et al., 2019; McMinn-Sauder et al., 2020; Wood et al., 2018). If honey bees are able to subsist by using forage in flowering habitats, then forage plantings specifically for honey bees may not need to include diverse and expensive seed mixes because honey bees are likely to target the protein rich flowering resources that are abundant in the local landscape. For example, our study suggests honey bees are likely to collect pollen from plantings that contain Trifolium, Plantago, and Solidago but adding additional species beyond this may not be cost-effective for improving honey bee protein diets. Other studies have noted that honey bees often visit and prefer inexpensive, non-native plants, providing additional evidence that seeding mixes specifically for honey bees can be designed at a reduced cost (Carr-Markell et al., 2020; McMinn-Sauder et al., 2020; Otto et al., 2017). We note, however, that increased forb diversity is likely to benefit native bee communities and that there is an important distinction between forage lands for honey bees and native bee habitat (Rollin et al., 2013).

We show that in a region with a diverse agroecosystem, protein content foraged by honey bees is spatially consistent, perhaps due to their large flight range and the presence of abundant forage in flowering habitats across land use categories. However, pollen protein is temporally variable and changes within and between years. Our findings add to the mounting evidence of temporal variation in honey bee-foraged 
pollen nutrition, which could help inform beekeepers' decision to supplement feed during periods of protein dearth. Our study also highlights the impact of forage abundance and protein content on honey bee pollen foraging at different times of the summer. Future research chould continue to experimentally investigate the role of multiple interacting factors influencing honey bee foraging behavior and how these effects change throughout the season. Furthermore, protein is only one aspect of pollen nutrition, so future studies chould also consider the balance of other pollen nutrients including lipids, micronutrients, amino acids and fatty acids, as well as access to sufficient nectar resources (Brodschneider and Crailsheim, 2010; Vaudo et al., 2015). Insights into temporal drivers of honey bee foraging behavior could greatly improve efforts to enhance honey bee nutrition and pollination services.

\section{Declaration of Competing Interest}

The authors declare that they have no known competing financial interests or personal relationships that could have appeared to influence the work reported in this paper.

\section{Acknowledgments}

Funding was provided by the USDA Farm Service Agency through Inter-agency Agreement 16IAMRECRPHBTA1. This material is based upon work supported by the National Science Foundation Graduate Research Fellowship under Grant No. DGE-1848739. We thank our collaborating beekeeper as well as the landowners who granted us access to their properties. We thank Michael Simanonok for providing code and guidance for working with pollen metabarcoding reads. We also acknowledge the technical field support of Sierra Barfield, Sarah Scott, Lidia Komondy, and Caitlyn Horsch. We gratefully acknowledge Vanessa Corby-Harris and the two anonymous reviewers for their feedback. Any use of trade, firm, or product names is for descriptive purposes only and does not imply endorsement by the U.S. government.

Genetic data have been submitted to NCBI under PRJNA685212 (https://www.ncbi.nlm.nih.gov/search/all/?term=PRJNA685212).

\section{Appendix A. Supplementary material}

Supplementary data associated with this article can be found in the online version at doi:10.1016/j.agee.2021.107645.

\section{References}

Aitchison, J., 1982. The statistical analysis of compositional data. J. R. Stat. Soc. Ser. B (Methodol.) 44, 139-177.

Alaux, C., Ducloz, F., Crauser, D., Le Conte, Y., 2010. Diet effects on honeybee immunocompetence. Biol. Lett. 6, 562-565. https://doi.org/10.1098/ rsbl.2009.0986.

Baldock, K.C.R., Goddard, M.A., Hicks, D.M., Kunin, W.E., Mitschunas, N., Morse, H., Osgathorpe, L.M., Potts, S.G., Robertson, K.M., Scott, A.V., Staniczenko, P.P.A., Stone, G.N., Vaughan, I.P., Memmott, J., 2019. A systems approach reveals urban pollinator hotspots and conservation opportunities. Nat. Ecol. Evol. 3, 363-373. https://doi.org/10.1038/s41559-018-0769-y.

Bates, D., Mächler, M., Bolker, B., Walker, S., 2015. Fitting linear mixed-effects models using lme4. J. Stat. Softw. 67. https://doi.org/10.18637/jss.v067.i01.

Beekman, M., Ratnieks, F.L.W., 2000. Long-range foraging by the honey-bee, Apis mellifera L. Funct. Ecol. 14, 490-496. https://doi.org/10.1046/j.13652435.2000.00443.x.

Beekman, M., Preece, K., Schaerf, T.M., 2016. Dancing for their supper: do honeybees adjust their recruitment dance in response to the protein content of pollen? Insect Soc. 63, 117-126. https://doi.org/10.1007/s00040-015-0443-1.

Bivand, R., Rundel, C., Pebesma, E., Stuetz, R., Hufthammer, K.O., Giraudoux, P., Davis, M., Santilli, S., 2019. Interface to Geometry Engine - Open Source ('GEOS').

Bretagnolle, V., Gaba, S., 2015. Weeds for bees? A review. Agron. Sustain. Dev. 35, 891-909. https://doi.org/10.1007/s13593-015-0302-5.

Brodschneider, R., Crailsheim, K., 2010. Nutrition and health in honey bees. Apidologie 41, 278-294. https://doi.org/10.1051/apido/2010012.

Brodschneider, R., Gratzer, K., Kalcher-Sommersguter, E., Heigl, H., Auer, W., Moosbeckhofer, R., Crailsheim, K., 2019. A citizen science supported study on seasonal diversity and monoflorality of pollen collected by honey bees in Austria. Sci. Rep. 9, 16633. https://doi.org/10.1038/s41598-019-53016-5.
Buchmann, S.L., 1986. Vibratile pollination in Solanum and Lycopersicon: a look at pollen chemistry. In: D’Arcy, W.G. (Ed.), Solanaceae: Biology and Systematics. Columbia University Press, New York, New York, USA, pp. 237-252.

Carr-Markell, M.K., Demler, C.M., Couvillon, M.J., Schürch, R., Spivak, M., 2020. Do honey bee (Apis mellifera) foragers recruit their nestmates to native forbs in reconstructed prairie habitats? PLOS One 15, 0228169. https://doi.org/10.1371/ journal.pone.0228169.

Chang, S.K.C., Zhang, Y., 2017. Protein analysis. In: Nielsen, S.S. (Ed.), Food Analysis, Food Science Text Series. Springer International Publishing, Cham, pp. 315-331. https://doi.org/10.1007/978-3-319-45776-5_18.

Cornman, R.S., Otto, C.R.V., Iwanowicz, D., Pettis, J.S., 2015. Taxonomic characterization of honey bee (Apis mellifera) pollen foraging based on nonoverlapping paired-end sequencing of nuclear ribosomal loci. PLOS One 10, 0145365. https://doi.org/10.1371/journal.pone.0145365.

Couvillon, M.J., Schürch, R., Ratnieks, F.L.W., 2014. Waggle dance distances as integrative indicators of seasonal foraging challenges. PLOS ONE. https://doi.org/ 10.1371/journal.pone.0093495.

Danner, N., Molitor, A.M., Schiele, S., Härtel, S., Steffan-Dewenter, I., 2016. Season and landscape composition affect pollen foraging distances and habitat use of honey bees. Ecol. Appl. 26, 1920-1929. https://doi.org/10.1890/15-1840.1.

DeGrandi-Hoffman, G., Chen, Y., Huang, E., Huang, M.H., 2010. The effect of diet on protein concentration, hypopharyngeal gland development and virus load in worker honey bees (Apis mellifera L.). J. Insect Physiol. 56, 1184-1191. https://doi.org/ 10.1016/j.jinsphys.2010.03.017.

DeGrandi-Hoffman, G., Chen, Y., Rivera, R., Carroll, M., Chambers, M., Hidalgo, G., de Jong, E.W., 2016. Honey bee colonies provided with natural forage have lower pathogen loads and higher overwinter survival than those fed protein supplements. Apidologie 47, 186-196. https://doi.org/10.1007/s13592-015-0386-6.

DeGrandi-Hoffman, G., Gage, S.L., Corby-Harris, V., Carroll, M., Chambers, M., Graham, H., Watkins deJong, E., Hidalgo, G., Calle, S., Azzouz-Olden, F., Meador, C., Snyder, L., Ziolkowski, N., 2018. Connecting the nutrient composition of seasonal pollens with changing nutritional needs of honey bee (Apis mellifera L.) colonies. J. Insect Physiol. 109, 114-124. https://doi.org/10.1016/j.jinsphys.2018.07.002.

Di Pasquale, G., Salignon, M., Conte, Y.L., Belzunces, L.P., Decourtye, A., Kretzschmar, A., Suchail, S., Brunet, J.-L., Alaux, C., 2013. Influence of pollen nutrition on honey bee health: do pollen quality and diversity matter? PLOS One 8, 72016. https://doi.org/10.1371/journal.pone.0072016.

Döke, M.A., Frazier, M., Grozinger, C.M., 2015. Overwintering honey bees: biology and management. Curr. Opin. Insect Sci. Soc. Insects Vectors Med. Vet. Entomol. 10, 185-193. https://doi.org/10.1016/j.cois.2015.05.014.

Donkersley, P., Rhodes, G., Pickup, R.W., Jones, K.C., Wilson, K., 2014. Honeybee nutrition is linked to landscape composition. Ecol. Evol. 4, 4195-4206. https://doi. org/10.1002/ece3.1293.

Fewell, J.H., Winston, M.L., 1992. Colony state and regulation of pollen foraging in the honey bee, Apis mellifera L. Behav. Ecol. Sociobiol. 30, 387-393. https://doi.org/ 10.1007/BF00176173.

Gallant, A.L., Euliss Jr., N.H., Browning, Z., 2014. Mapping large-area landscape suitability for honey bees to assess the influence of land-use change on sustainability of national pollination services. PLOS One 9, 99268. https://doi.org/10.1371/ journal.pone.0099268.

Goulson, D., Nicholls, E., Botías, C., Rotheray, E.L., 2015. Bee declines driven by combined stress from parasites, pesticides, and lack of flowers. Science 347, 1255957. https://doi.org/10.1126/science.1255957.

Haydak, M.H., 1935. Brood rearing by honeybees confined to a pure carbohydrate diet. J. Econ. Entomol. 28, 657-660. https://doi.org/10.1093/jee/28.4.657.

Hijmans, R.J., van Etten, J., Sumner, M., Cheng, J., Bevan, A., 2020. Geographic Data Analysis and Modeling.

Hothorn, T., Bretz, F., Westfall, P., 2008. Simultaneous inference in general parametric models. Biom. J. 50, 346-363. https://doi.org/10.1002/bimj.200810425.

Huson, D.H., Auch, A.F., Qi, J., Schuster, S.C., 2007. MEGAN analysis of metagenomic data. Genome Res. 17, 377-386. https://doi.org/10.1101/gr.5969107.

Joint Genome Institute, 2019. BBDuk Guide [WWW Document]. DOE Joint Genome Institute. URL: 〈https://jgi.doe.gov/data-and-tools/bbtools/bb-tools-user-guide/bbd uk-guide $/\rangle$. (Accessed 24 September 2019).

Khoury, D.S., Barron, A.B., Myerscough, M.R., 2013. Modelling food and population dynamics in honey bee colonies. PLOS One 8, 59084. https://doi.org/10.1371/ journal.pone.0059084.

Koh, I., Lonsdorf, E.V., Williams, N.M., Brittain, C., Isaacs, R., Gibbs, J., Ricketts, T.H., 2016. Modeling the status, trends, and impacts of wild bee abundance in the United States. Proc. Natl. Acad. Sci. 113, 140-145. https://doi.org/10.1073/ pnas.1517685113.

Langmead, B., Salzberg, S.L., 2012. Fast gapped-read alignment with Bowtie 2. Nat. Methods 9, 357-359. https://doi.org/10.1038/nmeth.1923.

Lau, P., Bryant, V., Ellis, J.D., Huang, Z.Y., Sulivan, J., Schmehl, D.R., Cabrera, A.R., Rangel, J., 2019. Seasonal variation of pollen collected by honey bees (Apis mellifera) in developed areas across four regions in the United States. PLOS ONE. https://doi.org/10.1371/journal.pone.0217294.

Levin, M., Bohart, G., 1955. Selection of pollens by honey bees. Am. Bee J. 95, 392-393.

Liolios, V., Tananaki, C., Dimou, M., Kanelis, D., Goras, G., Karazafiris, E., Thrasyvoulou, A., 2015. Ranking pollen from bee plants according to their protein contribution to honey bees. J. Apic. Res. 54, 582-592. https://doi.org/10.1080/ 00218839.2016.1173353.

MacConaill, L.E., Burns, R.T., Nag, A., Coleman, H.A., Slevin, M.K., Giorda, K., Light, M., Lai, K, Jarosz, M., McNeill, M.S., Ducar, M.D., Meyerson, M., Thorner, A.R., 2018. Unique, dual-indexed sequencing adapters with UMIs effectively eliminate index 
cross-talk and significantly improve sensitivity of massively parallel sequencing. BMC Genom. 19 https://doi.org/10.1186/s12864-017-4428-5, 30-30.

Mattila, H.R., Otis, G.W., 2007. Dwindling pollen resources trigger the transition to broodless populations of long-lived honeybees each autumn. Ecol. Entomol. 32, 496-505. https://doi.org/10.1111/j.1365-2311.2007.00904.x.

McMinn-Sauder, H., Richardson, R., Eaton, T., Smith, M., Johnson, R., 2020. Flowers in conservation reserve program (CRP) pollinator plantings and the upper Midwest agricultural landscape supporting honey bees. Insects 11, 405. https://doi.org/ 10.3390 /insects 11070405.

Michigan State University, 2020. Enviroweather [WWW Document]. URL: 〈envirowe ather.msu.edu/ $>$.

Otto, C.R.V., O’Dell, S., Bryant, R.B., Euliss, N.H., Bush, R.M., Smart, M.D., 2017. Using publicly available data to quantify plant-pollinator interactions and evaluate conservation seeding mixes in the Northern Great Plains. Environ. Entomol. 46, 565-578. https://doi.org/10.1093/ee/nvx070.

Otto, C.R.V., Zheng, H., Gallant, A.L., Iovanna, R., Carlson, B.L., Smart, M.D., Hyberg, S. 2018. Past role and future outlook of the conservation reserve program for supporting honey bees in the Great Plains. PNAS 115, 7629-7634. https://doi.org/ $10.1073 /$ pnas. 1800057115.

Pebesma, E., 2018. Simple features for R: standardized support for spatial vector data. R J. 10, 439-446.

Pernal, S.F., Currie, R.W., 2000. Pollen quality of fresh and 1-year-old single pollen diets for worker honey bees (Apis mellifera L.). Apidologie 31, 387-409. https://doi.org/ 10.1051/apido:2000130.

Pernal, S.F., Currie, R.W., 2001. The influence of pollen quality on foraging behavior in honeybees (Apis mellifera L.). Behav. Ecol. Sociobiol. 51, 53-68. https://doi.org/ $10.1007 /$ s002650100412.

Pernal, S.F., Currie, R.W., 2002. Discrimination and preferences for pollen-based cues by foraging honeybees, Apis mellifera L. Anim. Behav. 63, 369-390. https://doi.org/ 10.1006/anbe.2001.1904.

Pollinator Health Task Force, 2014. Presidential Memorandum - Creating a Federal Strategy to Promote the Health of Honey Bees and Other Pollinators [WWW Document]. Office of the Press Secretary. URL: 〈https://obamawhitehouse.archives. gov/the-press-office/2014/06/20/presidential-memorandum-creating-federal-strate gy-promote-health-honey-b $\rangle$. (Accessed 20 January 2020).

RCore Team, 2020. R: A Language and Environment for Statistical Computing. R Foundation for Statistical Computing, Vienna, Austria.

Quinlan, G.M., Milbrath, M.O., Otto, C.R.V, Isaacs, R., 2021. Farmland in U.S. Conservation Reserve Program has unique floral composition that promotes bee summer foraging. Basic and Applied Ecology. https://doi.org/10.1016/j baae.2021.08.011. In press.

Requier, F., Odoux, J.-F., Tamic, T., Moreau, N., Henry, M., Decourtye, A., Bretagnolle, V., 2015. Honey bee diet in intensive farmland habitats reveals an unexpectedly high flower richness and a major role of weeds. Ecol. Appl. 25, 881-890. https://doi.org/10.1890/14-1011.1.

Ribeiro, M.F., 2011. Growth in bumble bee larvae: relation between development time, mass, and amount of pollen ingested. Can. J. Zool. https://doi.org/10.1139/z94270.

Richardson, R.T., Lin, C.-H., Quijia, J.O., Riusech, N.S., Goodell, K., Johnson, R.M., 2015a. Rank-based characterization of pollen assemblages collected by honey bees using a multi-locus metabarcoding approach. Appl. Plant Sci. 3, 1500043 https:// doi.org/10.3732/apps.1500043.

Richardson, R.T., Lin, C.-H., Sponsler, D.B., Quijia, J.O., Goodell, K., Johnson, R.M., 2015b. Application of ITS2 metabarcoding to determine the provenance of pollen collected by honey bees in an agroecosystem. Appl. Plant Sci. 3, 1400066 https:// doi.org/10.3732/apps.1400066.

Rognes, T., Flouri, T., Nichols, B., Quince, C., Mahé, F., 2016. VSEARCH: a versatile open source tool for metagenomics. PeerJ 4, 2584. https://doi.org/10.7717/peerj.2584.

Rollin, O., Bretagnolle, V., Decourtye, A., Aptel, J., Michel, N., Vaissière, B.E., Henry, M., 2013. Differences of floral resource use between honey bees and wild bees in an intensive farming system. Agric. Ecosyst. Environ. 179, 78-86. https://doi.org/ 10.1016/j.agee.2013.07.007.

Roulston, T.H., Cane, J.H., 2002. The effect of pollen protein concentration on body size in the sweat bee Lasioglossum zephyrum (Hymenoptera: Apiformes). Evolut. Ecol. 16, 49-65. https://doi.org/10.1023/A:1016048526475.

Roulston, T.H., Cane, J.H., Buchmann, S.L., 2000. What governs protein content of pollen: pollinator preferences, pollen-pistil interactions, or phylogeny? Ecol. Monogr. 70, 617-643. https://doi.org/10.1890/0012-9615(2000)070[0617: WGPCOP] 2.0.CO;2.

Schmidt, J.O., Thoenes, S.C., Levin, M.D., 1987. Survival of honey bees, Apis mellifera (Hymenoptera: Apidae), fed various pollen sources. Ann. Entomol. Soc. Am. 80, 176-183. https://doi.org/10.1093/aesa/80.2.176.

Seeley, T.D., 1986. Social foraging by honeybees: how colonies allocate foragers among patches of flowers. Behav. Ecol. Sociobiol. 19, 343-354. https://doi.org/10.1007/ BF00295707.
Simanonok, M.P., Otto, C.R.V., Smart, M.D., 2020. Do the quality and quantity of honey bee-collected pollen vary across an agricultural land-use gradient? Environ. Entomol. 49, 189-196. https://doi.org/10.1093/ee/nvz139.

Simanonok, M.P., Otto, C.R.V., Cornman, R.S., Iwanowicz, D.D., Strange, J.P., Smith, T. A., 2021. A century of pollen foraging by the endangered rusty patched bumble bee (Bombus affinis): inferences from molecular sequencing of museum specimens. Biodivers. Conserv. 30, 123-137. https://doi.org/10.1007/s10531-020-02081-8.

Smart, M.D., Pettis, J.S., Euliss, N., Spivak, M.S., 2016. Land use in the Northern Great Plains region of the U.S. influences the survival and productivity of honey bee colonies. Agriculture, Ecosystems \& Environment. https://doi.org/10.1016/j. agee.2016.05.030.

Smart, M.D., Cornman, R.S., Iwanowicz, D.D., McDermott-Kubeczko, M., Pettis, J.S Spivak, M.S., Otto, C.R.V., 2017. A comparison of honey bee-collected pollen from working agricultural lands using light microscopy and ITS metabarcoding. Environ. Entomol. 46, 38-49. https://doi.org/10.1093/ee/nvw159.

Smart, Matthew D., Otto, C.R.V., Cornman, R., Iwanowicz, D., 2018a. Using colony monitoring devices to evaluate the impacts of land use and nutritional value of forage on honey bee health. Agriculture 8, 2. https://doi.org/10.3390/ agriculture8010002.

Smart, M.D., Otto, C.R.V., Carlson, B.L., Roth, C.L., 2018b. The influence of spatiotemporally decoupled land use on honey bee colony health and pollination service delivery. Environ. Res. Lett. 13, 084016 https://doi.org/10.1088/17489326/aad4eb.

Smart, M.D., Otto, C.R.V., Lundgren, J.G., 2019. Nutritional status of honey bee (Apis mellifera L.) workers across an agricultural land-use gradient. Sci. Rep. 9, 16252. https://doi.org/10.1038/s41598-019-52485-y.

Stanford, A.M., Harden, R., Parks, C.R., 2000. Phylogeny and biogeography of Juglans (Juglandaceae) based on matK and ITS sequence data. Am. J. Bot. 87, 872-882.

State of Michigan, 2021. Michigan Invasive Species - Herbs [WWW Document]. URL 〈https://www.michigan.gov/invasives/0,5664,7-324-68002_71240_73853-,00. html $\rangle$. (Accessed 13 January 2021).

Steffan-Dewenter, I., Kuhn, A., 2003. Honeybee foraging in differentially structured landscapes. Proc. R. Soc. Lond. Ser. B Biol. Sci. 270, 569-575. https://doi.org/ 10.1098/rspb.2002.2292.

Thogmartin, W.E., López-Hoffman, L., Rohweder, J., Diffendorfer, J., Drum, R., Semmens, D., Black, S., Caldwell, I., Cotter, D., Drobney, P., Jackson, L.L., Gale, M., Helmers, D., Hilburger, S., Howard, E., Oberhauser, K., Pleasants, J., Semmens, B., Taylor, O., Ward, P., Weltzin, J.F., Wiederholt, R., 2017. Restoring monarch butterfly habitat in the Midwestern US: 'all hands on deck'. Environ. Res. Lett. 12, 074005 https://doi.org/10.1088/1748-9326/aa7637.

Tritschler, M., Vollmann, J.J., Yañez, O., Chejanovsky, N., Crailsheim, K., Neumann, P., 2017. Protein nutrition governs within-host race of honey bee pathogens. Sci. Rep. 7, 14988. https://doi.org/10.1038/s41598-017-15358-w.

US Department of Agriculture National Agricultural Statistics Service, 2018. Croplands Data Layer [WWW Document]. URL: 〈https://nassgeodata.gmu.edu/CropScape/>. (Accessed 23 March 2020).

vanEngelsdorp, D., Meixner, M.D., 2010. A historical review of managed honey bee populations in Europe and the United States and the factors that may affect them. J. Invertebr. Pathol. 103, S80-S95. https://doi.org/10.1016/j.jip.2009.06.011.

Vaudo, A.D., Tooker, J.F., Grozinger, C.M., Patch, H.M., 2015. Bee nutrition and floral resource restoration. Curr. Opin. Insect Sci. Soc. Insects Vectors Med. Vet. Entomol. 10, 133-141. https://doi.org/10.1016/j.cois.2015.05.008.

Vaudo, A.D., Tooker, J.F., Patch, H.M., Biddinger, D.J., Coccia, M., Crone, M.K., Fiely, M., Francis, J.S., Hines, H.M., Hodges, M., Jackson, S.W., Michez, D., Mu, J., Russo, L., Safari, M., Treanore, E.D., Vanderplanck, M., Yip, E., Leonard, A.S. Grozinger, C.M., 2020. Pollen protein: lipid macronutrient ratios may guide broad patterns of bee species floral preferences. Insects 11. https://doi.org/10.3390/ insects11020132.

White, T., Bruns, T., Lee, S., Taylor, J., Innis, M., Gelfand, D., Sninsky, J., 1990 Amplification and direct sequencing of fungal ribosomal RNA genes for phylogenetics. PCR Protocols: A Guide to Methods and Applications, pp. 315-322.

Williams, I.H., 2003. The convention on biological diversity adopts the international pollinator initiative. Bee World 84, 27-31. https://doi.org/10.1080/ 0005772X.2003.11099568.

Wood, T.J., Kaplan, I., Szendrei, Z., 2018. Wild bee pollen diets reveal patterns of seasonal foraging resources for honey bees. Frontiers in Ecology and Evolution. https://doi.org/10.3389/fevo.2018.00210.

Ziska, L.H., Pettis, J.S., Edwards, J., Hancock, J.E., Tomecek, M.B., Clark, A., Dukes, J.S., Loladze, I., Polley, H.W., 2016. Rising atmospheric $\mathrm{CO}_{2}$ is reducing the protein concentration of a floral pollen source essential for North American bees. Proc. Biol. Sci. 283. https://doi.org/10.1098/rspb.2016.0414.

State Search Results. USDA Plants Database, 2020. URL: 〈https://plants.usda.gov/java /stateSearch). (Accessed 03 December 2020). 